\title{
Non-volant small mammals at an Atlantic forest area situated nearby a limestone quarry (Limeira quarry), state of São Paulo, Brazil
}

\author{
Natália Oliveira Leiner ${ }^{1,3}$ \& Wesley Rodrigues Silva ${ }^{2}$ \\ ${ }^{1}$ Instituto de Biologia, Universidade Federal de Uberlândia - UFU, Campus Umuarama, \\ CEP 38400-902, Uberlândia, MG, Brazil \\ ${ }^{2}$ Laboratório de Interações Vertebrados-Plantas, Departamento de Biologia Animal, \\ Universidade Estadual de Campinas - UNICAMP, Campinas, SP, Brazil \\ ${ }^{3}$ Corresponding author: Natália Oliveira Leiner, e-mail: naleiner@gmail.com
}

LEINER, N.O. \& SILVA, W.R. Non-volant small mammals at an Atlantic forest area situated nearby a limestone quarry (Limeira quarry), state of São Paulo, Brazil. Biota Neotrop. 12(4): http://www. biotaneotropica.org.br/v12n4/en/abstract?inventory+bn02312042012

\begin{abstract}
Our aim was to survey the non-flying small mammals inhabiting an Atlantic forest area situated nearby a limestone quarry (Limeira quarry), located at Ribeirão Grande municipality (SP), southeastern Brazil. Species were captured with pitfall and Sherman traps along eight pairs of $60 \mathrm{~m}$ transects distributed at four different distances from the quarry $(60,220,740$ and $1300 \mathrm{~m})$. Between October 2005 and January 2008, 20 small mammal species (11 rodents and nine marsupials) were captured through 4080 pitfall trap-nights and 2040 Sherman trapnights. The high values of richness, diversity $\left(\mathrm{H}^{\prime}=2.65\right)$ and equability $(\mathrm{J}=0.88)$, and the presence of endemic and threatened species indicates a preserved study site and small mammal assemblage. Marmosops incanus, Monodelphis americana and Oligoryzomys nigripes were the commonest species at the study site. Trapping sites located closer to the quarry ( 60 and $220 \mathrm{~m}$ away from the quarry) presented lower richness and were dominated by disturbance-tolerant species, such as $O$. nigripes, that usually benefit from habitat alterations. On the other hand, sites located away from the quarry and closer to Serra do Mar Protected Area (740 and 1300 m away from the quarry) presented higher richness and diversity, and a higher abundance of disturbance-intolerant species. These results suggest a negative distance-dependent impact of quarrying on small mammal communities. In this way, our results point out to the importance of long-term monitoring of quarrying impacts on small nonflying mammal communities and populations, and the need of conservation strategies in order to ensure species persistence in these areas.
\end{abstract}

Keywords: biodiversity, faunistic inventory, mining impacts, Didelphimorphia, Rodentia.

LEINER, N.O. \& SILVA, W.R. Pequenos mamíferos não-voadores em uma área de Mata Atlântica adjacente à mina de cimento Limeira, São Paulo, Brasil. Biota Neotrop. 12(4): http://www.biotaneotropica.org.br/v12n4/ pt/abstract?inventory+bn02312042012

Resumo: O objetivo desse estudo foi elaborar uma lista das espécies de pequenos mamíferos não-voadores que ocorrem em uma região de Mata Atlântica localizada nas proximidades de uma área de mineração de calcário (Mina Limeira), situada no município de Ribeirão Grande (SP), sudeste do Brasil. Para tal, foram montadas estações de captura contendo linhas de balde e armadilhas do tipo Sherman em oito transectos de $60 \mathrm{~m}$, agrupados em pares e localizados a diferentes distâncias da cava da mina (60, 220, 740 e 1300 m de distância), partindo da área antropizada em direção à área de proteção ambiental da Serra do Mar. Entre outubro de 2005 e janeiro de 2008, com um esforço de 4080 baldes-noite e 2040 armadilhas-noite, foram capturadas 20 espécies de pequenos mamíferos, sendo 11 roedores e nove marsupiais. A alta riqueza, diversidade $\left(H^{\prime}=2,65\right)$ e equabilidade $(J=0,88)$ estimada na área de estudo, além da presença de espécies endêmicas e ameaçadas, indicam o grau de preservação da área de estudo e da assembléia de pequenos mamíferos. As espécies mais comuns foram Marmosops incanus, Monodelphis americana e Oligoryzomys nigripes. Os transectos localizados mais próximos da cava (60 e $220 \mathrm{~m}$ de distância) foram dominados por espécies indicadoras de habitats alterados, como $O$. nigripes, que tende a proliferar nessas situações. Por outro lado, os sítios mais distantes (740 e 1300 m de distância da cava) apresentaram maior riqueza e diversidade, e espécies mais sensíveis a perturbações. Esses resultados sugerem um possível impacto negativo dependente de distância em relação à mina de calcário. Dessa maneira, nossos resultados apontam para a importância de monitoramentos de longo prazo sobre os impactos da mineração sobre as populações e a comunidade de pequenos mamíferos não-voadores, além da elaboração de planos de conservação para assegurar a persistência das espécies na região.

Palavras-chave: biodiversidade, inventário faunístico, impacto da mineração, Didelphimorphia, Rodentia. 


\section{Introduction}

Currently, the Atlantic Forest corresponds to only $12 \%$ of its original range, which is restricted to small forest fragments and areas disturbed by anthropogenic activities (Ribeiro et al. 2009). Among the disturbances, forest clearance, habitat loss and alterations in landscape configuration and vegetation structure at the local scale represent the major threats to biodiversity (Primack 2004). Despite such threats, this biome retains at least $7 \%$ of the world biodiversity, along with several endemic species (Myers et al. 2000).

Opencast mining, which is used to extract surface minerals such as coal and limestone, imposes important risks to the surrounding ecosystem. First, mining activities require suppression of original vegetation, thus causing habitat loss and changes in plant species composition and habitat structure due to edge effects (Harper et al. 2005). Second, blasting of rocks for mining excavation presents several impacts such as 1) air pollution, 2) enhancement of dust deposition, which may affect plants by reducing their photosynthesis, respiration and transpiration (Farmer 1993) and soil dwelling invertebrates through changes in soil chemical parameters (MacKenzie et al. 1990), 3) noise and vibrations, which may influence soil stability, water regimes (Ak et al. 2009), and sound perception by terrestrial animals, thus reducing their foraging and reproductive abilities (Barber et al. 2009). Finally, these activities may also cause soil erosion, alterations in nutrient cycling and hydrological flows (Farias 2002, Companhia... 2003). Such habitat deterioration, along with habitat reduction, may alter the structure of animal communities and species distribution (Tews et al. 2004).

Non-volant small mammals are highly diverse in the Neotropics (Ceballos \& Ehrlich 2006, Patterson 2000, Voss \& Emmons 1996). Besides their numerical importance, members of this group may function as good biological indicators due to their susceptibility to environmental impacts and disturbances related to alterations in habitat structure (Pardini et al. 2005). Moreover, both didelphids and rodents are crucial to the maintenance of trophic links and regulation of predator populations through their role as food supply to birds (Cabral et al. 2006), snakes (Henderson et al. 1987) and carnivorous mammals (Facure \& Monteiro-Filho 1996). Finally, both may contribute to ecosystem functioning and habitat restoration, since they act as pollination agents (Vieira et al. 1991) and dispersers of seeds and mycorrhizal fungi (Grelle \& Garcia 1999, Mangan \& Adler 2000).

The main objective of this study was to provide an inventory of the non-volant small mammal fauna inhabiting an Atlantic Forest area directly affected by a limestone quarry ("Limeira quarry"), located in the Planalto de Guapiara, Ribeirão Grande municipality. This region, along with Vale do Ribeira, contains approximately $40 \%$ of São Paulo's state conservation units (Capobianco 1992). In this way, our results may 1) contribute to the understanding of the impacts of mining activities on the small mammal communities, and 2) provide information for the elaboration of conservation and management plans for small mammal species in the region.

\section{Materials and Methods}

Limeira limestone quarry (24 $94^{\prime} 41^{\prime \prime} \mathrm{S}$ and $\left.48^{\circ} 21^{\prime} 3^{\prime \prime} \mathrm{W}\right)$ is located approximately $15 \mathrm{~km}$ from Ribeirão Grande municipality, southeastern São Paulo state. The quarry is situated nearby to a large Atlantic forest area, which is part of the Paranapiacaba ecological continuum, considered one of the largest remnants of Atlantic forest along with four other conservation units in the proximities (Parque Estadual Intervales, Estação Ecológica de Xitué, Parque Estadual Carlos Botelho and Parque Estadual Turístico do Alto Ribeira) (Figure 1). The climate is characterized as subtropical humid ( $\mathrm{Cfb}$ in Koeppen's classification), with a rainy season from October to March and a cold and less rainy season from April to September. Mean annual temperature is approximately $19{ }^{\circ} \mathrm{C}$ and precipitation ranges from 1600 to 1800 per year. During the cold and less rainy season, average monthly temperature is about $14.3{ }^{\circ} \mathrm{C}\left(\mathrm{SD}=1.97{ }^{\circ} \mathrm{C}\right)$ and average monthly rainfall is $44.4 \mathrm{~mm}(\mathrm{SD}=36.52 \mathrm{~mm})$, while in the rainy season average monthly temperature is about $18.7^{\circ} \mathrm{C}\left(\mathrm{SD}=2.41^{\circ} \mathrm{C}\right)$ and average monthly rainfall is $196.1 \mathrm{~mm}(\mathrm{SD}=93.64 \mathrm{~mm})$. The vegetation in the region is composed by disturbed forests, to mature forests dominated by Myrtaceae, Rubiaceae, Annonaceae and Melastomataceae (Companhia... 2003).

Animals were captured using pitfall and Sherman traps, which were set at four different distances $(60,220,740$ and $1300 \mathrm{~m})$ from the limestone quarry. Closer to the mine (Site 1), the habitat is characterized by secondary, disturbed forest, with a dense understory situated in steep hills and high abundance of rocks covering the soil. Site 2 is also composed by secondary forest, with several vegetation gaps. The canopy is about $15-20 \mathrm{~m}$ high, understory is very dense and there is a shallow leaf litter layer. Site 3 is the most preserved, with canopy reaching 30-35 m high, open understory, high leaf litter abundance and a large bromeliad and liana density. Site 4 resembles site 3 , but contains vegetation gaps dominated by secondary forest embedded in the preserved forest.

At each distance, a pair of $60 \mathrm{~m}$ transects distant approximately $300 \mathrm{~m}$ from each other were set, totalizing eight independent transects. We trapped monthly during three consecutive nights from October 2005 to March 2006, and then bimonthly until January 2008, totalizing 17 capture sessions (Table 1 ). At each transect we set a $60 \mathrm{~m}$ sequence of pitfall traps (buckets of 601 ), located approximately $6 \mathrm{~m}$ from each other, and connected by a wire mesh fence of $0.5 \mathrm{~m}$ high. To capture strictly arboreal species, Sherman traps $(31 \times 8 \times 9 \mathrm{~cm})$ baited with smoked sausage were fixed at trees (1.5-2 m high), equidistant in $12 \mathrm{~m}$, along each transect (see Table 1). Two previous studies using smoked sausage at nearby Fazenda Intermontes achieved high capture success of several small mammal species, including Brucepattersonius spp., O. nigripes, S. angouya, Oxymycterus spp. and Akodon spp. (Gaspar, unpublished results, Leiner 2009).

Each captured individual was processed immediately, by recording body mass, sex and reproductive condition. Females were considered reproductive when they presented swollen nipples, young in the pouch (marsupials), or if they were pregnant, which could be observed in a few cases by palpation. Male rodents were considered reproductive whenever they presented scrotal testes. On the other hand, reproductive condition of male marsupials was not assessed; once the male's testes become scrotal when they reach sexual maturity, they stay in this position permanently, precluding an accurate evaluation of their reproductive activity (Quental et al. 2001). Individuals were also marked with numbered ear tags (Zootech,

Table 1. Sampling effort at Limeira quarry and surroundings from October 2005 to January 2008.

\begin{tabular}{lcccc}
\hline \multicolumn{1}{c}{ Sampling effort } & Number of capture nights & Sherman & Pitfall & Total \\
\hline Per transect & 3 & 5 & 10 & 15 Sherman and 30 pitfall traps \\
Per capture session & 3 & 40 & 80 & 120 Sherman and 240 pifall traps \\
Total (17 capture sessions) & 51 & & & 2040 Sherman trap-nights and 4080 \\
& & & & Pitfall trap-nights \\
\hline
\end{tabular}




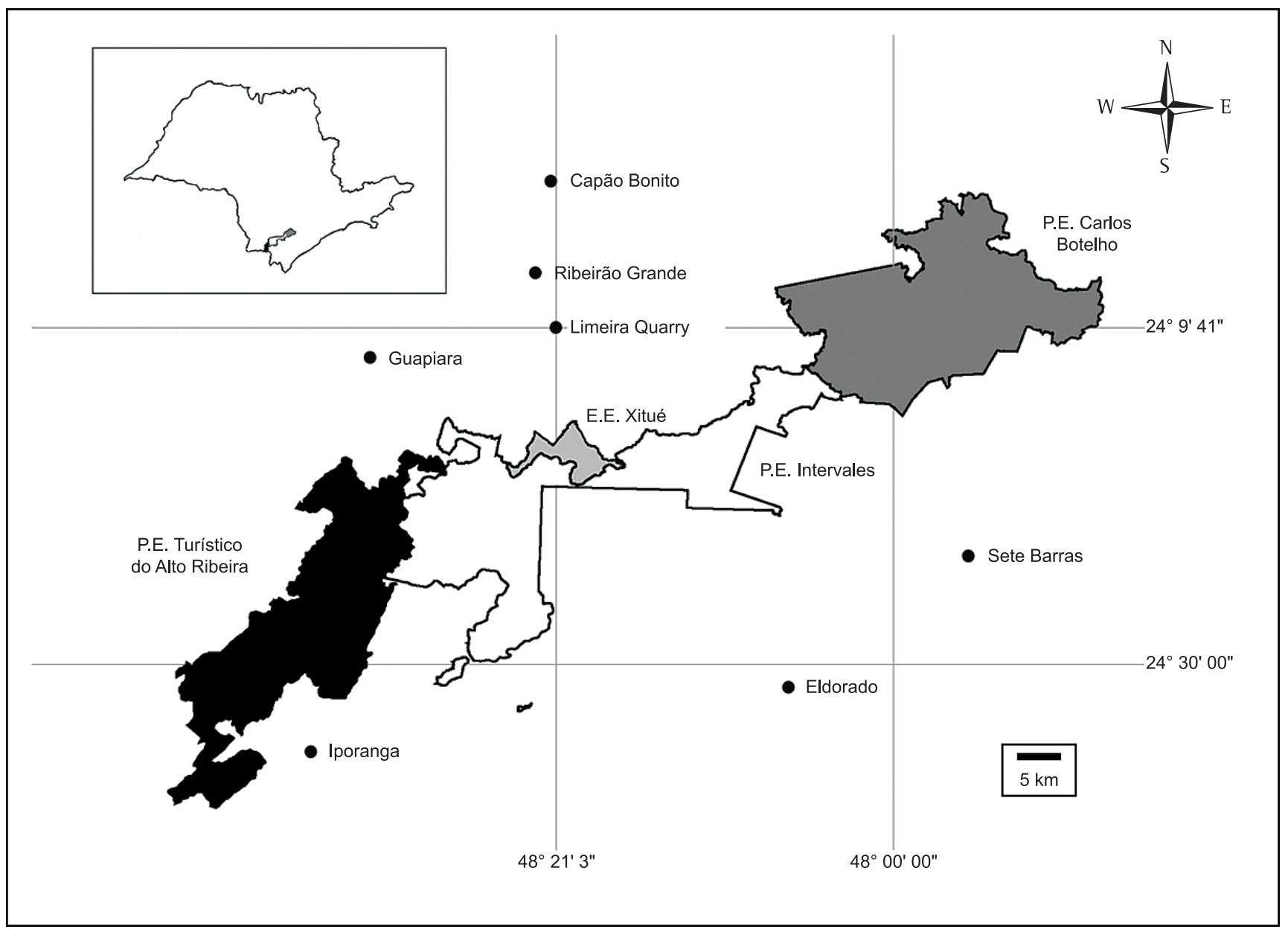

Figure 1. Paranapiacaba ecological continuum location in São Paulo state, and in detail the location of Limeira quarry in relation to Capão Bonito and Ribeirão Grande municipalities and their nearby state conservation units, which are part of the ecological continuum of Paranapiacaba Range.

Curitiba), and their species diagnosed using external characters, such as biometric data (body length, tail length, hind foot length and ear length - all measured in $\mathrm{mm}$ ) and patterns of dorsal and ventral coloration (Bonvicino et al. 2008, Emmons \& Feer 1997), and released in the same capture point. Both pitfall and Sherman traps were closed in the end of each capture session.

Between August 2006 and July 2007, 28 individuals were collected and had their skins prepared and their skulls cleaned with dermestid beetles, for further identification based on cranial characters. Such specimens were deposited as voucher specimens in the mammal collection of the Museu de Zoologia da Universidade de São Paulo (MZUSP) (IBAMA/ICMBio License number 296/2007).

Sample rarefaction curves were constructed in order to evaluate if sampling effort was adequate to capture most species at the study site. We used Jackknife second-order estimator to estimate expected species richness in the community. Sampling rarefaction and species richness were estimated using software PAST, which was also used to calculate Shannon-Wiener diversity index (H') for the community and per sampled site and equability $\left(\mathrm{J}^{\prime}\right)$ for the whole community. Diversity indices were also compared between sites by Hutcheson's t test using PAST.

\section{Results}

From October 2005 to January 2008, 99 non-volant small mammal specimens were captured through a sampling effort of 2040 live trap-nights and 4080 pitfall trap-nights. A total of 20 species $\left(H^{\prime}=2.65\right)$ were recorded, including eight sigmodontinae rodents, three echimyid rodents and nine didelphid marsupials (Table 2). The number of genera and species captured were very similar, since only Marmosops, Didelphis and Monodelphis presented two species in the study site. Voucher specimens received field numbers (in parenthesis) and were identified as follows: $P$. frenatus (56), P. nigrispinus (55), S. angouya $(53,54), K$. amblyonyx (38), E. subspinosus (45), D. sublineatus $(5,36,49,51,62)$, O. nigripes $(34,46,66)$, E. russatus (50) and D. albimaculatus (47, 48 - fluid preserved). We were unable to identify Brucepattersonius (37, 52 and 57) and Akodon (59) at the species level, due to the lack of tissues for molecular and karyotipic analysis.

The rarefaction curve (Figure 2) indicates a decrease in the rate of capture of new species, thus demonstrating that we approached the real number of species with our sampling effort. Actually, richness estimated by Jackknife $2(21.42 \pm 4.7)$ corroborates this result. Marsupials represented $49 \%$ of the captured individuals, followed by Muridae (44\%) and Echymyidae (2\%). Among Sigmodontinae, tribes Akonditini (three species registered - Akodon sp. 1, Brucepattersonius sp. 1 and Thaptomys nigrita), and Oryzomyini (four species registered - Drymoreomys albimaculatus, Euryoryzomys russatus, Oligoryzomys nigripes and Sooretamys angouya) were equally abundant (20 and 19\% of captured individuals, respectively), while Delomys sublineatus, which is classified as incertae sedis, was underrepresented (7\%). Captured species were mainly omnivorous, 


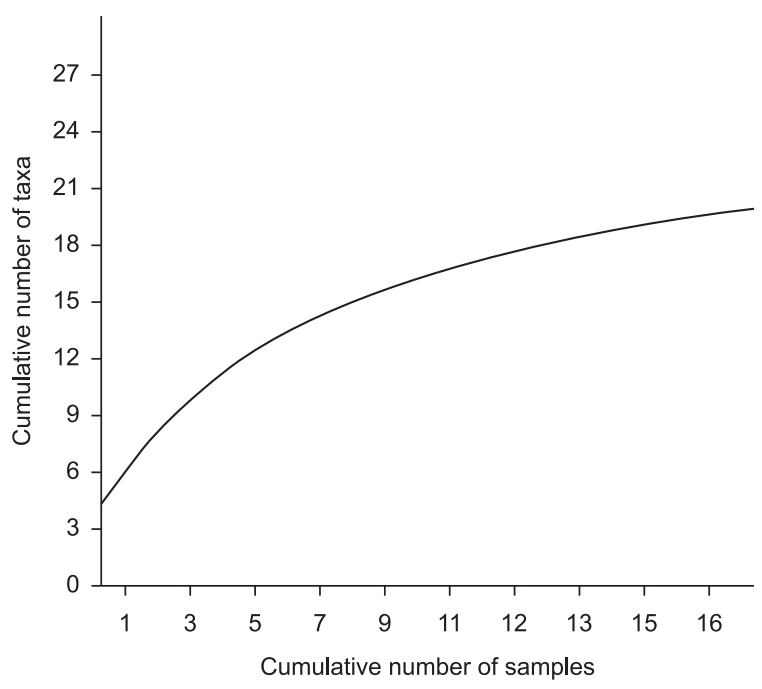

Figure 2. Mean curve of the increased number of species registered with the increase in sampling effort (rarefaction curve) at Limeira quarry and surroundings from October 2005 to January 2008.

Table 3. Species richness (S) and Shannon's diversity index (H') of small non-flying mammals captured at the four trapping sites, which were located at different distances from the quarry, and considering the entire Limeira quarry Atlantic forest remnant.

\begin{tabular}{ccc}
\hline Site & Richness & Diversity \\
\hline 1 & 7 & 1.75 \\
2 & 8 & 1.94 \\
3 & 16 & 2.55 \\
4 & 14 & 2.41 \\
Total & 20 & $\mathbf{2 . 6 5}$ \\
\hline
\end{tabular}

Table 4. Comparison of diversity (H's) values between sites located at different distances from the quarry, using Hutcheson's t test. Significant differences between sites are marked in bold.

\begin{tabular}{cccc}
\hline Site & $\mathbf{2}$ & $\mathbf{3}$ & $\mathbf{4}$ \\
\hline 1 & $\mathrm{t}=0.87, \mathrm{p}=0.4$ & $\mathbf{t}=\mathbf{3 . 7}, \mathbf{p}=\mathbf{0 . 0 0 0 5}$ & $\mathbf{t}=\mathbf{2 . 1 8}, \mathbf{p}=\mathbf{0 . 0 3}$ \\
2 & - & $\mathbf{t}=\mathbf{2 . 9 7 ,} \mathbf{p}=\mathbf{0 . 0 0 4}$ & $\mathrm{t}=1.49, \mathbf{p}=0.14$ \\
3 & - & - & - \\
4 & - & - & - \\
\hline
\end{tabular}

between site 2 and 4 is probably due to similarities in habitat structure prior to mining activities. Site 4, although far away from the quarry $(1300 \mathrm{~m})$, presents several vegetation gaps dominated by secondary forest.

A few marsupials and rodents were restricted to one or two sites. However, the low number of captures for most species, usually inferior to five, precludes habitat selection evaluation. Marmosops incanus, Monodelphis americana and Oligoryzomys nigripes, were captured at all sites. Actually, $O$. nigripes was more abundant at disturbed sites, since a high number of individuals belonging to this species were found in the sites closer to the quarry (six and 4 individuals in sites 1 and 2) when compared to sites away from the quarry ( 2 individuals in sites 3 and 4), which are considered less-disturbed. Thaptomys nigrita and Marmosops paulensis were absent only from site 1. Finally, Kannabateomys amblyonyx, Gracilinanus microtarsus, Didelphis aurita, Euryoryzomys russatus, Euryzygomatomys spinosus, Phyllomys nigrispinus, Drymoreomys albimaculatus and
Metachirus nudicaudatus were very uncommon, being captured only once or twice in a single site (see Table 2).

\section{Discussion}

Twenty terrestrial small mammal species were captured at the study site, being nine marsupials and 11 rodents. Compared to other Atlantic forest areas, the Limeira quarry area and its surroundings presented higher species richness than several preserved, continuous Atlantic forest areas and also disturbed forest fragments. Actually, the sites that presented similar or higher species richness than our study site (e.g. Parque Nacional do Caparaó, Parque Nacional de Itatiaia, Reserva Florestal do Morro Grande, Parque Estadual Intervales, Parque Estadual Carlos Botelho and Parque Estadual Turístico do Alto Ribeira) usually encompass larger protected areas, higher altitudinal variation and include data collected over several years, by several researchers and including museum information (Bonvicino et al. 1997, Geise et al. 2004, Pardini \& Umetsu 2006, Vivo \& Gregorin 2001, Hingst-Zaher \& Machado 2008, Hingst-Zaher et al. 2010). As discussed by Pardini \& Umetsu (2006), in their inventory in Morro Grande Reserve, it is also possible that the use of pitfall traps played a role in the high values of species richness found in Mina Limeira. This method ensures high capture rates because 1) several specimens may be captured in the same trap (Umetsu et al. 2006) and 2) captures are independent of bait attraction and bait preferences (Adler \& Lambert 1997, Laurance 1992). Moreover, pitfall traps seem to be quite efficient to capture semifossorial small mammals (Pardini 2004), which are usually absent in communities sampled only with Sherman live traps.

In the study site, non-volant small community presented several intermediary or rare species and only a few dominant ones, which corroborates its high equability. Such pattern is common among natural communities (Magurran 2004), including small mammal assemblages in cerrado and Atlantic Forest areas (Bonvicino et al. 2002, Carmignotto \& Aires 2011). Equability values may work as proxies to community conservation status, since disturbed areas usually present low values due to dominance by a few disturbance-tolerant species that manage to proliferate in altered sites (Bonvicino et al. 2002). The high equability estimates at Limeira quarry and surroundings suggests habitat preservation. However, at a smaller spatial scale, we observe a different pattern at site 1 , where the community is dominated by few species, especially $O$. nigripes, which presents a high relative abundance, and is considered benefitted by habitat disturbances (Pardini 2004). These results indicate that mining impacts may be distance-dependent, and that although the community as whole is preserved, there are important changes occurring at smaller spatial scales, especially closer to the quarry.

Sampled sites presented differences in species richness and diversity, with a pattern of higher values at sites 3 and 4, which presented habitat resembling mature forests and were located away from the quarry. Such differences corroborate the distance-dependent impact of mining activities in small mammal fauna, although more replicas of each site are necessary. Mining may affect species diversity through reduced availability of food resources (fruits and invertebrates) due to a decrease in plant productivity, reduced litter volume due to soil erosion and changes in plant community composition due to edge effects. Moreover, vibrations caused by blasting of rocks may influence foraging and anti-predator defense of small mammals (Schmidt \& Ostfeld 2008, Rabin et al. 2006), thus affecting individual fitness and long-term population persistence. In this way, future tests should evaluate the role of each of these impacts in small mammal assemblages and population dynamics. 
Several small mammals are considered resilient to habitat disturbances and changes in vegetation structure (Malcolm 1997), while others are clearly disturbance-intolerant, being associated to mature forests (Pardini et al. 2005). Earlier studies have already demonstrated that $O$. nigripes and scansorial marsupials, such as M. incanus, are associated to secondary, fragmented forests (Pardini 2004, Rocha et al. 2011), as we found at Limeira quarry. On the other hand, T. nigrita, Monodelphis species and Marmosops paulensis are usually associated to less-disturbed, preserved sites (Pardini \& Umetsu 2006). Although we were unable to clearly evaluate habitat selection, due to the low number of captures, in our study both T. nigrita and $M$. paulensis were absent from site 1 . The proximity to the quarry may contribute to reduce litter volume, thus decreasing the availability of nest-sites for semi-fossorial species, such as T. nigrita, and soil fauna used as food resources by both species.

The captured species at Limeira quarry and surroundings correspond to approximately $24 \%$ of the São Paulo state non-volant small mammal fauna (Percequillo \& Kierulff 2009). Six of the observed species at our study site are endemic to the Atlantic forest, including Marmosops paulensis, which is considered as vulnerable in São Paulo state due to its restricted distribution (Percequillo \& Kierulff 2009). Another four marsupial species captured around the Limeira quarry (Monodelphis americana, Monodelphis scalops, Metachirus nudicaudatus and Marmosops incanus) are categorized as near threatened in São Paulo state, due to habitat loss and fragmentation (Percequillo \& Kierulff 2009). Furthermore, two rodent species found in the area, Thaptomys nigrita and Euryoryzomys russatus, are also considered as vulnerable in São Paulo state (Percequillo \& Kierulff 2009). The high species diversity and the occurrence of several endemic and threatened small mammal species, along with rare and habitat specialist ones, points out to the conservation status of this Atlantic forest remnant and the importance of preserving this site. Moreover, our results demonstrate that mining and its associated habitat disturbances failed to negatively influence small mammal species diversity and composition, although it seems that negative impacts are restricted to sites closer to the quarry. In this way, mining impacts may occur at smaller spatial scales, being distance-dependent, or may occur only at the population level for this small mammal assemblage.

In the future, long-term monitoring plans, usually required as a legislative compliance in mining offsets, should continue to evaluate the impacts of quarrying in small mammal communities. Long-term monitoring should focus on population dynamics and behavioral ecology of species, especially those considered rare and habitat specialists, which are though to be more threatened by mining activities and their consequences. In order to ensure species persistence we suggest the implementation of three different conservation actions: 1) preserve the forest remnant surrounding Limeira quarry through the creation of a protected area, 2) keep noise and vibrations at appropriate levels, in order to reduce disturbance for animals and prevent further soil erosion, 3) implement forest corridors between this remnant and the adjacent state conservation units, once the maintenance of genetic and individual flow between areas may help to prevent population reduction and species extinction.

\section{Acknowledgements}

We are indebted to Companhia de Cimento Ribeirão Grande (CCRG), who provided logistical and financial support, and two anonymous referees that improved manuscript quality with their suggestions. Dr. Alexandre Percequillo helped with species identification. Finally, Natalia Leiner was sponsored by Coordenação de Aperfeiçoamento de Pessoal do Nível Superior during the inventory.

\section{References}

ADLER, G.H. \& LAMBERT, T.D. 1997. Ecological correlates of trap response of a neotropical forest rodent, Proechimys semispinosus. J. Trop. Ecol. 13:59-68. http://dx.doi.org/10.1017/S0266467400010257

AK, H., IPHAR, M., YAVUZ, M. \& KONUK, A. 2009. Evaluation of ground vibration effect of blasting operations in a magnesite mine. Soil Dyn. Earthquake Eng. 29:669-676. http://dx.doi.org/10.1016/j. soildyn.2008.07.003

BARBER, J.R., CROOKS, K.R. \& FRISTRUP, K.M. 2009. The costs of chronic noise exposure for terrestrial organisms. Trends Ecol. Evol. 25:180-189. PMid:19762112. http://dx.doi.org/10.1016/j. tree.2009.08.002

BONVICINO, C.R., DE OLIVEIRA, J.A. \& D'ANDREA, P.S. 2008. Guia dos roedores do Brasil, com chaves para gêneros baseadas em caracteres externos. Centro Pan-Americano de febre Aftosa-OPAS/OMS, Rio de Janeiro.

BONVICINO, C.R., LANGGUTH, A., LINDBERGH, S.M. \& PAULA, A.C.1997. An elevational gradient study of small mammals at Caparaó National Park, South eastern Brazil. Mammalia 61:547-560.

BONVICINO, C.R., LINDBERGH, S.M. \& MAROJA, L.S. 2002. Small nonflying mammals from conserved and altered areas of Atlantic forest and Cerrado: comments on their potential use for monitoring environment. Braz. J. Biol. 62:765-774. PMid:12659027. http://dx.doi.org/10.1590/ S1519-69842002000500005

CABRAL, J.C., GRANZINOLLI, M.A.M. \& MOTTA-JUNIOR, J.C. 2006. Dieta do quiriquiri, Falco sparverius (Aves: Falconiformes) na Estação Ecologica de Itirapina, São Paulo. Ararajuba 14:393-399.

CAPOBIANCO, J.R. 1992. Dossiê da Mata Atlântica. Fundação SOS Mata Atlântica, São Paulo.

CARMIGNOTTO, A.P. \& AIRES, C.C. 2011. Mamíferos não voadores (Mammalia) da Estação Ecológica Serra Geral do Tocantins. Biota Neotrop. 11:313-328. http://dx.doi.org/10.1590/S167606032011000100029

CEBALLOS, G. \& EHRLICH, P. 2006. Global mammal distributions, biodiversity hotspots and conservation. PNAS 103:19374-19379. PMid:17164331 PMCid:1698439. http://dx.doi.org/10.1073/ pnas.0609334103

COMPANHIA DE CIMENTO RIBEIRÃO GRANDE. 2003. Ampliação da Mina Limeira: estudo de impacto ambiental. São Paulo, v.2, v.6.

EMMONS, L.H. \& FEER, F. 1997. Neotropical Rainforest Mammals: a field guide. The University of Chicago Press, Chicago.

FACURE, K.G. \& MONTEIRO-FILHO, E.L.A. 1996. Feeding habits of the crab-eating fox, Cerdocyon thous (Carnivora, Canidae), in a suburban area of southeastern Brazil. Mammalia 60:147-149.

FARIAS, C.E.G. 2002. Mineração e meio ambiente no Brasil. Centro de Gestão e Estudos Estratégicos, São Paulo. Relatório.

FARMER, A.M. 1993. The effects of dust on vegetation- a review. Environ. Pollution 79:63-75. http://dx.doi.org/10.1016/0269-7491(93)90179-R

GEISE, L., PEREIRA, L.G., BOSSI, D.E. \& BERGALlO, H.G. 2004. Patterns of elevational distribution and richness of nonvolant mammals in Itatiaia National Park and surroundings, in Southeastern Brazil. Braz. J. Biol. 64:1-15. http://dx.doi.org/10.1590/S1519-69842004000400007

GRELLE, C.E.V. \& GARCIA, Q.S. 1999. Potential dispersal of Cecropia hololeuca by the common opossum (Didelphis aurita) in Atlantic forest, southeastern Brazil. Rev. Ecol.-Terre Vie 54:327-332.

HARPER, K.A., MacDONALD, S.E., BURTON, P.J., CHEN, J., BROSOFSKE, K.D., SANDERS, S.C., EUSKIRCHEN, E.S., ROBERTS, D. \& ESSEEN, P.A. 2005. Edge influence on forest structure and composition in fragmented landscapes. Cons. Biol. 19:768-782. http:// dx.doi.org/10.1111/j.1523-1739.2005.00045.x 
HENDERSON, R.W., SCHWARTZ, A. \& NOESKE-HALLIN, T.A. 1987. Food habits of three colubrid tree snakes (genus Uromacer) on Hispaniola. Herpetologica 43:241-248.

HINGST-ZAHER, E. \& MACHADO, F.A. 2008. Plano de manejo do Parque Estadual Carlos Botelho e Estação Ecológica de Xitué. Módulo Biodiversidade. Instituto Ekos Brasil, Instituto Florestal de São Paulo, São Paulo. Relatório Pequenos Mamíferos.

HINGST-ZAHER, E., MACHADO, F.A., DE OLIVEIRA, M.V.B. \& FORLANI, M. 2010. Plano de Manejo do Parque Estadual Turístico do Alto Ribeira. Instituto Ekos Brasil, Instituto Florestal de São Paulo, São Paulo. Relatório Pequenos Mamíferos.

LAURANCE, W.F. 1992. Abundance estimates of small mammals in Australian tropical rainforest: a comparison of four trapping methods. Wildlife Res. 19:651-655. http://dx.doi.org/10.1071/WR9920651

LEINER, N.O. 2009. Padrões de uso do espaço em múltiplas escalas espaciais por roedores e marsupiais de Mata Atlântica. Tese de doutorado, Universidade Estadual de Campinas, Campinas.

LEINER, N.O., DICKMAN, C.R. \& SILVA, W.R. 2010. Multiscale habitat selection by slender opossums (Marmosops spp.) in the Atlantic forest of Brazil. J. Mammal. 91:561-565. http://dx.doi.org/10.1644/09MAMM-A-328.1

MacKENZIE, S., LEE, J.A. \& WRIGHT, J.M. 1990. Ecological impact of liming blanket bog. Nature Conservancy Council, Peterborough. CSD Report No 1167.

MAGURRAN, A.E. 2004. Measuring biological diversity. Blackwell Publishing, Oxford.

MALCOLM, J.R. 1997. Biomass and diversity of small mammals in Amazonian forest fragments. In Tropical forest remnants: ecology, management and conservation of fragmented communities (W.F. Laurance \& R.O. Bierregard, eds.). University of Chicago Press, Chicago, p.207-221.

MANGAN, S.A. \& ADLER, G.H. 2000. Consumption of arbuscular mycorrhizal fungi by terrestrial and arboreal small mammals in a Panamanian cloud forest. J. Mammal. 81:563-570. http://dx.doi. org/10.1644/1545-1542(2000)081<0563:COAMFB >2.0.CO;2

MYERS, N., MITTERMEIER, R.A., MITTERMEIER, C.G., FONSECA, G.A.B. \& KENT, J. 2000. Biodiversity hotspots for conservation priorities. Nature 403:853-858. PMid:10706275. http://dx.doi. org $/ 10.1038 / 35002501$

PARDINI, R. 2004. Effects of forest fragmentation on small mammals in an Atlantic forest landscape. Biodivers. Conserv. 13:2567-2586. http:// dx.doi.org/10.1023/B:BIOC.0000048452.18878.2d

PARDINI, R., SOUZA, S.M., BRAGA-NETO, R. \& METZGER, J. P. 2005. The role of forest structure, fragment size and corridors in maintaining small mammal abundance and diversity in an Atlantic forest landscape. Biol. Conserv. 124:253-266. http://dx.doi.org/10.1016/j. biocon.2005.01.033
PARDINI, R. \& UMETSU, F. 2006. Pequenos mamíferos não-voadores da Reserva Florestal do Morro Grande - distribuição das espécies e da diversidade em uma área de Mata Atlântica. Biota Neotrop. 6:1-22. http:// dx.doi.org/10.1590/S1676-06032006000200007

PATTERSON, B.D. 2000. Patterns and trends in the discovery of new Neotropical mammals. Divers. Distrib. 6:145-151. http://dx.doi. org/10.1046/j.1472-4642.2000.00080.x

PERCEQUILLO, A.R. \& KIERULFF, M.C.M. 2009. Mamíferos. In Fauna ameaçada de extinção no estado de São Paulo (P.M. Bressan, M.C.M Kierulff, A.M. Sugieda, orgs.). Fundação Parque Zoológico de São Paulo, Secretaria do Meio Ambiente, São Paulo, v.1, p.32-35.

PRIMACK, R. 2004. A primer of conservation biology. 3rd ed. Sinauer Associates, Sunderland.

RABIN, L.A., COSS, R.G. \& OWINGS, D.H. 2006. The effects of wind turbines on antipredator behavior in California ground squirrels (Spermophilus beecheyi). Biol.Conserv. 131:410-420. http://dx.doi. org/10.1016/j.biocon.2006.02.016

QUENTAL, T.B, FERNANDEZ, F.A.S., DIAS, A.T.C. \& ROCHA, F.S. 2001 Population dynamics of the marsupial Micoureus demerarae in small fragments of Atlantic Coastal Forest in Brazil. J. Trop. Ecol. 17:339-352. http://dx.doi.org/10.1017/S0266467401001237

RIBEIRO, M.C., METZGER, J.P., MARTENSEN, A.C., PONZONI, F. \& HIROTA, M. 2009. Brazilian Atlantic forest: how much is left and how is the remaining forest distributed? Implications for conservation. Biol. Conserv. 142:1141-1153. http://dx.doi.org/10.1016/j.biocon.2009.02.021

ROCHA, M.F., PASSAMANI, M. \& LOUZADA, J. 2011. A small mammal community in a forest fragment, vegetation corridor and coffee matrix system in the Brazilian Atlantic Forest. PlosOne 6:1-8. PMid:21912591 PMCid:3166140. http://dx.doi.org/10.1371/journal.pone.0023312

SCHMIDT, K.A. \& OSTFELD, R.S. 2008 Eavesdropping squirrels reduce their future value of food under the perceived presence of cache robbers. Am. Nat. 171:388-393. PMid:18220481. http://dx.doi. org $/ 10.1086 / 527497$

TEWS, J., BROSE, U., GRIMM, V., TIELBORGEN, K., WICHMANN, M.C., SCHWAGER, M. \& JELTSCH, F. 2004. Animal species diversity driven by habitat heterogeneity/diversity: the importance of keystone structures. J. Biogeogr. 31:79-92. http://dx.doi.org/10.1046/j.03050270.2003.00994.x

UMETSU, F., NAXARA, L. \& PARDINI, R. 2006. Evaluating the efficiency of pitfall traps for sampling small mammals in the Neotropics. J. Mammal. 87:757-765. http://dx.doi.org/10.1644/05-MAMM-A-285R2.1

VIEIRA, M.F., CARVALHO-OKANO, R.M. \& SAZIMA, M. 1991. The common opossum, Didelphis marsupialis, as a pollinator of Mabea fistulifera (Euphorbiaceae). Cien. Cultura 43:390-393.

VIVO, M. \& GREGORIN, R. 2001. Mamíferos. In Intervales (C. Leonel, coord.). Fundação para a Conservação e a Produção Florestal do Estado de São Paulo, São Paulo, p.116-123.

VOSS, R. \& EMMONS, L.H. 1996. Mammalian diversity in Neotropical lowland forest: a preliminary assessment. Bull. Am. Mus. Nat. Hist. 230:1-115. 